\title{
Effect of an individualised high-protein, energy-restricted diet on anthropometric and cardio-metabolic parameters in overweight and obese Malaysian adults: a 6-month randomised controlled study
}

\author{
Soma Roy Mitra* and Pui Yee Tan* \\ School of Biosciences, Faculty of Science, University of Nottingham Malaysia, Jalan Broga, 43500 Semenyih, Selangor Darul \\ Ehsan, Malaysia \\ (Submitted 13 October 2018 - Final revision received 27 January 2019 - Accepted 4 February 2019 - First published online 05 April 2019)
}

\section{Abstract}

The aim of this study was to investigate the effectiveness of the Hipcref (high-protein, energy-restricted, high-vitamin E and high-fibre) diet in Malaysian adults on body composition and metabolic parameters after an intervention period of 6 months. Overweight/obese Malaysian adults ( $n$ 128; BMI $\geq 23 \mathrm{~kg} / \mathrm{m}^{2}$ ) were randomised to the Hipcref $(n 65)$ or control diet $(n 63)$. The intervention group received Hipcref diet charts based on their personal preferences. The control group followed a generalised dietary advice based on Malaysian Dietary Guidelines, 2010. All participants were responsible for preparing their own meals. There was a significant treatment group $\times$ time effect on anthropometric parameters $(P<0.05)$ on an intention-to-treat basis. Pairwise comparisons revealed that Hipcref diet participants had significant reduction in weight, BMI, waist circumference, fat mass and percentage body fat at months 3 and 6 compared with baseline $(P<0 \cdot 001)$. The control group had significant increase in weight and BMI at months 3 and 6 compared with baseline $(P<0 \cdot 05)$. The Hipcref diet group had higher reduction in fasting insulin, insulin resistance and C-reactive protein levels compared with the control group at month $6(P<0 \cdot 05)$. Post-intervention, compared with the control group, the Hipcref diet group was found to consume significantly higher percentage energy from protein, and PUFA, higher energy-adjusted vitamin $\mathrm{E}(\mathrm{mg})$ and fibre $(\mathrm{g})$, and lower total energy, lower percentage energy from fat and carbohydrate $(P<0.05)$. The success of the Hipcref diet on overweight/obese Malaysian adults may be due to the combined effect of the nutrient composition of the Hipcref diet.

\section{Key words: High-protein diet: Energy-restricted diet: Cardio-metabolic parameters: Interventions: Malaysian adults}

The prevalence of obesity is increasing worldwide, and it is now classified as a disease ${ }^{(1)}$. Obesity is a major public health problem and has clinical implications in increasing the prevalence of comorbid conditions such as hypertension, hyperglycaemia, dyslipidaemia, insulin resistance and inflammation $^{(2)}$. National Health and Morbidity Survey 2015 reported that 5.6 million Malaysian adults aged 18 and above were overweight and 3.3 million were obese ${ }^{(3)}$. According to Tan et $a l .{ }^{(4)}$, the treatment of obesity and its primary comorbidities are estimated to cost the Malaysian health care system approximately US\$162 million per year. Therefore, the recent challenge is to develop an effective and sustainable weight loss intervention programme to combat high prevalence of obesity in the Malaysian population.

Previous evidence has illustrated that a moderate weight loss of $5-10 \%$ in body weight ${ }^{(5,6)}$, particularly in visceral adipose tissue $^{(7-9)}$, showed beneficial effects in insulin sensitivity, glycaemic control and CVD risk. However, over the years, strategies to combat obesity remained ineffective, particularly in long-term weight loss programmes ${ }^{(10)}$. Past studies have investigated interventions based on various dietary patterns by varying the dietary macronutrient composition ${ }^{(11,12)}$. Other strategies that have been used to facilitate weight management include reduction in energy density, portion control through meal replacement and improved diet quality ${ }^{(13-16)}$. A key strategy for weight management that can be applied across dietary patterns is to reduce energy density of meals. Clinical trials show that reducing energy density is effective for weight loss and weight loss maintenance ${ }^{(17,18)}$.

A high-protein diet is potentially effective in promoting satiety, reducing energy intake, inducing weight loss and maintaining lean muscle tissue ${ }^{(19,20)}$. A high-protein diet with $25-$ $30 \%$ of total energy (TE) from protein showed greater reduction in weight and waist circumference (WC) and greater

Abbreviations: Hipcref, high-protein, energy-restricted, high vitamin E and fibre; HOMA-IR, homoeostatic model assessment-insulin resistance; hsCRP, high-sensitivity C-reactive protein; MDG, Malaysian Dietary Guidelines; TE, total energy; UNM, University of Nottingham Malaysia; WC, waist circumference.

* Corresponding authors: S. R. Mitra, fax +6 38924 8018, email Soma.Mitra@nottingham.edu.my; P. Y. Tan, fax +6 389248018 , email khyx4tpe@nottingham.edu.my 
improvement in glycaemic control and cardio-metabolic profile in Asian Indians, Iranian and Australian populations ${ }^{(21-23)}$. A study by Gulati et al. ${ }^{(21)}$ indicated that protein-enriched meal replacement resulted in significant weight loss, improved insulin sensitivity and reduction in inflammatory parameters in overweight and obese Asian Indians. However, it is unknown whether commercial products (meal replacements) lead to a better understanding of portion control of habitual meals beyond the intervention period ${ }^{(24)}$. Therefore, it is essential to identify an effective food-based dietary strategy which is costeffective, culturally sensitive and practical under real-life situations for long-term weight control.

General recommendations based on dietary guidelines, for example, recommended nutrient intake or $\mathrm{RDA}$, are often ineffective and end in unsuccessful weight management programmes as there is no one-size-fits-all diet that is more effective than others. A recent review by Koliaki et al. ${ }^{(25)}$ reported that a dietary regimen to manage obesity should be safe, efficacious, nutritionally adequate, culturally sensitive, cost-effective, adoptable and should ensure long-term maintenance of weight loss. Setting a realistic weight loss goal and following a balanced dietary plan tailored according to an individual's needs and food preferences are key to facilitating sustainable weight loss and reduction in metabolic risk in obese individuals. Ethnic diversity in Malaysia is unique (Bumiputera - 69.1\%, Chinese $-23 \%$, Indians $-6.9 \%$ and others $-1 \%)^{(26)}$. According to a recent study, Malaysians of different ethnic background continue to practise traditional meal patterns, habitually ${ }^{(27)}$. Individualised dietary intervention according to cultural preferences could be more effective in establishing the individual's adherence to the intervention diet and promote successful and sustainable weight management.

This study is nested in a broader study investigating the association of SNP in fat mass and obesity-associated (FTO) gene with obesity traits and their interaction with dietary factors in Malaysian adults of three different ethnic groups. We found significant interaction between FTO rs9930506 with dietary protein and vitamin $\mathrm{E}$ on high-sensitivity $\mathrm{C}$-reactive protein (hsCRP) levels ${ }^{(28)}$. Strong association of FTO gene and obesityrelated traits have been consistently observed in studies involving various populations worldwide ${ }^{(29-31)}$. There is evidence of significant inverse association between dietary vitamin $\mathrm{E}$ and hsCRP levels in some populations ${ }^{(32,33)}$. Therefore, in the present study, we introduced a Hipcref (high-protein, energy-restricted, high-vitamin $\mathrm{E}$ and high-fibre) diet to increase percentage energy from protein and included food sources that contributed to $\geq 15 \mathrm{mg} / \mathrm{d}$ of vitamin $\mathrm{E}$ for better metabolic outcome.

The aim of this study was to assess the effect of a Hipcref diet (an energy deficit of $1255-2092 \mathrm{~kJ} / \mathrm{d}, 30 \%$ energy from protein, $30 \%$ energy from fat, $40 \%$ energy from carbohydrate, vitamin $\mathrm{E}$ $\geq 15 \mathrm{mg} / \mathrm{d}$ and fibre $\geq 25 \mathrm{~g} / \mathrm{d}$ ) on obesity-related anthropometric and blood biochemical parameters (e.g. fasting glucose, fasting insulin, homoeostatic model assessment-insulin resistance (HOMA-IR), hsCRP and lipid levels), in overweight and obese Malaysian adults, compared with the control diet group. The control diet group received generalised dietary advice on weight loss according to the Malaysian Dietary Guidelines
(MDG) 2010 ( $<6276 \mathrm{~kJ} / \mathrm{d}$ with a macronutrient composition of approximately 10-15\% energy from protein, 20-30\% energy from fat and $55-70 \%$ energy from carbohydrate). The intervention group received individual diet charts based on their personal preferences, likes/dislikes, traditional customs and meal times. Each individual chart, prescribed, calculated values of energy, macronutrient, vitamin $\mathrm{E}$ and fibre intake per $\mathrm{d}$. All participants were responsible for obtaining their own food ingredients and preparing their own meals.

\section{Methods}

\section{Ethical approval}

This study was conducted according to the guidelines laid down in the Declaration of Helsinki, and all procedures involving human subjects were reviewed and approved by the University of Nottingham in Malaysia Science and Engineering Research Ethics Committee. This study was registered under the Medical Research and Ethics Committee of National Medical Research Registry (Research ID-25110), Ministry of Health Malaysia. Written informed consent was requested and obtained from all willing participants.

\section{Participant selection}

This study is nested in a broader study investigating the effect of gene-diet interaction on obesity-related traits. Detailed information on the study design and method has been described in our previous publication ${ }^{(28)}$. Briefly, a total of 178 Malaysian adults (Malaysian Chinese, Malays and Indians) aged 18 years and above were recruited to investigate gene-diet interactions on obesity-related traits. Participants were recruited at random through advertisements and flyers distributed at University of Nottingham Malaysia (UNM) campus, supermarkets and schools in the vicinity of UNM. Interested participants completed a health and lifestyle questionnaire, which included questions on ethnic background, past diseases, family history of past diseases, physical activity level and substance abuse. Smoking status and alcohol consumption were reported as (i) never, (ii) former and (iii) current. Individuals diagnosed with CVD, diabetes, cancer, hypertension, renal diseases, endocrine disorders such as hypothyroidism were excluded. Individuals on medications for cholesterolaemia, hypoglycaemia and psychiatric disorders were excluded. Pregnant and lactating women were also excluded from the study. Interested individuals attended initial screening to determine whether or not the participant met the inclusion and exclusion criteria.

In the present randomised dietary intervention study, only overweight and obese Malaysian adults (Malaysian Chinese, Malays and Indians) aged 18 years and above with a BMI $\geq 23 \mathrm{~kg} / \mathrm{m}^{2}$ were recruited from the parent study. Six waves of recruitment (cohorts) had staggered start dates between March 2015 and October 2017, as illustrated in online Supplementary Fig. S1. A total of 128 participants who met the inclusion criteria were selected to participate in the present intervention study. 


\section{Study design}

This study was designed as a 6-month randomised, controlled and parallel-arm study to assess the effect of the Hipcref diet on anthropometric and cardio-metabolic parameters in overweight and obese Malaysian adults compared with the control diet group. Participants were categorised into two based on (a) sex (female and male) and (b) by ethnicity (Malaysian Chinese, Malays and Indians), using block randomisation technique. The randomised list was provided to the study team who added eligible participants sequentially to two groups, the intervention group and the control group. Therefore, 128 participants were randomly assigned to one of the two treatments: Hipcref diet group ( $n$ 65) or control diet group ( $n$ 63).

\section{High-protein, energy-restricted, high vitamin E and fibre diet (intervention diet)}

Mode of delivery. At baseline, diet intake was assessed as reported earlier. Attention was paid to details of personal preferences (vegetarian, non-vegetarian), likes/dislikes, food customs and meal times and documented. Based on the baseline energy intake, a reduction of $1255-2092 \mathrm{~kJ} / \mathrm{d}$ of TE intake (depending on the range of energy intake) was computed. The composition of the macronutrients of the revised diet provided $30 \%$ of energy from protein, $30 \%$ of energy from fat and $40 \%$ energy from carbohydrate. In all, $30 \%$ energy content of protein energy of the revised energy intake was converted to protein intake in $\mathrm{g} / \mathrm{d}$. This quantity was then translated to protein-rich food sources. An example menu for a typical day was planned and charted. The food sources that were entered in the menu plan were matched with the individual's likes, dislikes and personal preferences. Chicken, pork, egg and fish such as salmon, mackerel, sardines, tuna, anchovy, but not red meat, were charted for the non-vegetarian participants. Plant-based foods (including soya bean and products, tofu, chickpea and yellow/ red lentils) and dairy products (including low-fat/skimmed milk, low-fat plain yogurt and soft cream cheese) were charted for the vegetarian participants. For instance, (a) in case of nonvegetarian preference, steamed chicken breast, $120 \mathrm{~g}$ (approximately $29 \mathrm{~g}$ of protein), was advised. Individuals were requested to consume at least three servings of the latter per $\mathrm{d}$. In case of (b) vegetarian preference, steamed tofu, $200 \mathrm{~g}$ (approximately $16 \mathrm{~g}$ of protein), was advised. Participants were requested to consume at least five to six servings of the latter per d. Dietary counselling was provided to Hipcref participants on examples of prescribed portion sizes with the aid of photographs. The total protein in grams on the prescribed diet charts ranged from 73.1 to $98.5 \mathrm{~g}(4163-5326 \mathrm{~kJ} / \mathrm{d} ; 28-31 \%$ of energy from protein).

A similar approach was taken with respect to fat intake. The fats and oils used to cook meals were recorded in the structured questionnaire for all individuals. The number of family members the food was cooked for was recorded as well. Daily use of cooking oil/butter/margarine was quantified for the participant in the prescribed chart. The quantity of oil/butter/margarine per $\mathrm{d}$ prescribed to the individual was multiplied by the number of family members times 30 to arrive at a total quantity of cooking medium per month to be used for the whole family. The participants were advised to adhere to the above quantity of fats and oils and not go beyond the prescribed quantity.

Same approach was taken with respect to formulation of energy from carbohydrate. The computed carbohydrate energy content were converted to carbohydrate intake in $\mathrm{g} / \mathrm{d}$. This quantity was then translated to high-fibre, complex carbohydrate-rich foods and entered in the individual diet charts and menu plans.

Prescription of vitamin $E \geq 15 \mathrm{mg} / d$ and fibre $\geq 25 \mathrm{~g} / \mathrm{d}$. Food sources such as vegetable oil (including sunflower oil, palm oil and rapeseed oil), nuts (including almonds, peanuts, hazelnuts and walnuts), seeds (including sunflower seeds) and green leafy vegetables (including broccoli and spinach) were included into the Hipcref diet to increase participant's vitamin E intake. Previous studies have reported on a favourable metabolic profile with a high-fibre diet ${ }^{(34,35)}$. Therefore, we included fibre intake of $\geq 25 \mathrm{~g} / \mathrm{d}$ in the prescribed diet chart as per MDG $2010^{(36)}$. We included leafy green vegetables (broccoli, spinach, carrots, etc.), legumes (chickpeas, peas, lentils, etc.), fruits (apple, pear, guava, etc.), muesli, whole grain cereals and oat products to increase soluble and non-soluble dietary fibre to the Hipcref diet.

The entire consultation programme was revised and modified once a month throughout the intervention period to maximise participant adherence to the programme and to minimise monotony. Participants were responsible for obtaining their own food ingredients and preparing their own meals, following the guidelines laid down in the prescribed chart. The meal times on the prescribed chart did not deviate from the baseline diet survey of each individual. Healthier recipe options were listed in the prescribed chart (online Supplementary Table S1) given to each individual on the Hipcref diet. Participants were advised to choose healthier meal preparation techniques, such as steaming, boiling, grilling and baking. Consumption of raw salad was advised. When dining out, individuals were advised to avoid sambal (chilli and palm sugar paste in oil), oily gravy, etc. to reduce TE intake.

\section{Control diet}

Mode of delivery. Participants allocated to the control diet group ( $n$ 63) did not receive an individualised prescribed diet chart. Generalised dietary advice on weight loss was provided to them based on the MDG 2010 ${ }^{(36)}$. MDG 2010 consists of a food pyramid to promote healthy eating and active lifestyle among the Malaysian population. Control diet participants were advised to reduce their TE intake and consume no more than $6276 \mathrm{~kJ}$ of energy per d (the energy intake recommended for sedentary activity) ${ }^{(36)}$. This quantity of TE intake per $d$ was translated to food-based dietary counselling as follows: four servings of cereals and grains $(30 \mathrm{~g}$ of carbohydrate per serving), two servings of fruits, three servings of vegetables, one serving of fish (14 $\mathrm{g}$ of protein per serving), $1 / 2$ serving of meat/poultry ( $14 \mathrm{~g}$ of protein per serving), $1 / 2$ serving of legumes ( $7 \mathrm{~g}$ of protein per serving) and one serving of milk 
and dairy products ( $7 \mathrm{~g}$ of protein per serving) per $\mathrm{d}^{(36)}$. Participants were also advised to consume low-fat food and less sugar and salt in general ${ }^{(36)}$. These food portions provided approximately 10-15\% energy from protein, $20-30 \%$ energy from fat and $55-70 \%$ energy from carbohydrate ${ }^{(36)}$. Participants were responsible for obtaining their own food ingredients and preparing their own meals.

All participants were registered on WhatsApp and Facebook to convey necessary messages to them from the research team at the shortest possible time. The majority of the study participants were categorised as physically inactive at baseline $(90 \cdot 8-$ 98.4\%; Table 3). All participants were asked to maintain their usual levels of physical activity and to refrain from drinking and smoking during the intervention period. Throughout the 6-month intervention period, monthly meetings took place at UNM or at a designated venue to monitor the changes in body composition and provide dietary counselling.

\section{Measurement of anthropometric parameters}

Measurements of anthropometric parameters were taken at baseline, month 3 and month 6 of the intervention period. Height of the individual (barefoot) was measured with a standard height rod. Body composition including weight, fat mass (kg), skeletal muscle mass ( $\mathrm{kg})$, fat-free mass $(\mathrm{kg})$ and percentage body fat (\%) were measured using a body composition analyser DSM-BIA InBody 230 (InBody Co., Ltd.). BMI was arrived at using the formula, weight in kg divided by the height in metre square $\left(\mathrm{kg} / \mathrm{m}^{2}\right)$. Overweight and obesity was defined as BMI $23-27.4 \mathrm{~kg} / \mathrm{m}^{2}$ and $\mathrm{BMI} \geq 27.5 \mathrm{~kg} / \mathrm{m}^{2}$, respectively ${ }^{(37)}$. WC was measured at the midpoint between lower margin of palpable rib and the top of iliac crest. Hip circumference was measured at the widest portion of the buttocks ${ }^{(38)}$. Waist:hip ratio (WHR) was calculated using the ratio of the circumference of the waist to the hip. Systolic and diastolic blood pressure was measured using a digital blood pressure monitor, following the recommendation from American Heart Association (AHA) ${ }^{(39)}$.

\section{Dietary assessment}

Dietary data were collected and assessed at baseline and month 6 of the intervention period. Energy, macro- and micronutrient intake were assessed by an interviewer-administered validated FFQ. Twenty-four hour recalls were conducted on all participants to capture and include food items habitually consumed on weekdays and weekends ${ }^{(40)}$. Food items included in the validated $\mathrm{FFQ}^{(41)}$ were then modified to include items popular to all three ethnic groups collected from the $24 \mathrm{~h}$ recalls. This FFQ consisted of 156 food items which were listed according to twelve categories (grain, meat and poultry, fish and seafood, egg and eggs products, legumes, milk and milk products, vegetables, fruits, drinks, confectionary, bread spread and flavourings). Detailed information related to the brands of purchased food items, methods of cooking, fat and oil consumption and supplementation intake were included to capture macro- and micronutrient intake as accurately as possible. For each item, participants indicated the frequency of consumption for the past week (never, once a week, 2-4 times a week, 5-6 times a week, once per d, 2-3 times/d, 4-5 times/d). The number of standard portions consumed per sitting was recorded with the aid of photographs of standard portion sizes $^{(42)}$. Total daily intake of macro- and micronutrients was calculated by multiplying the energy and nutrient content of unit portion of each food item by the number of portions consumed per sitting, times a factor representing the frequency of consumption for the past week and finally summed across all food items to give an estimate of the total daily energy, macro- and micronutrient intake per day. The per day consumption data were entered into an energy and nutrient assessment software, Dietplan7 (Forestfield Software Ltd) to compute energy, macro- and micronutrient intake. All food items not found in the Dietplan7 database were keyed in from

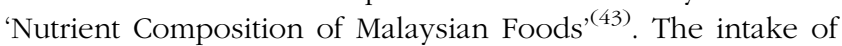
macronutrients including SFA, MUFA, PUFA and trans-fatty acids (TFA) were expressed as a percentage of TE consumed. TE:BMR ratio $<1.2$ was used to identify under-reporters of energy intake ${ }^{(44)}$. In the present study, none of the participants was found to be under-reporting. Therefore, all participants were included for data analysis. BMR for adult Malaysians was predicted from the equations based on age group, sex and body weight $(\mathrm{kg})^{(45)}$ (Table 1$)$.

\section{Physical activity}

Physical activity data were collected through an intervieweradministered structured questionnaire at baseline and month 6 of the intervention period. The questionnaire included a list of physical activities with corresponding metabolic equivalent (MET) values ${ }^{(46)}$. Details of activities asked included (1) the type and intensity of the activity (e.g. jogging, brisk walking, running etc.); (2) the time and duration (min) of each activity performed per $\mathrm{d}$ and (3) the number of days each activity was performed in a week. The reported physical activity was then categorised into light, moderate and vigorous intensity physical activity which was defined as <3 MET, 3-6 MET and >6 MET, respectively, according to Ainsworth et al. ${ }^{(46)}$. The total time (min) spent on sedentary, moderate and vigorous intensity physical activity in a week was computed for each participant. According to the Ministry of Health Malaysia, individuals who accumulate at least $150 \mathrm{~min} /$ week of moderate intensity physical activity or $60 \mathrm{~min} /$ week of vigorous intensity physical activity are considered as physically active, else they are considered as physically inactive ${ }^{(36)}$. Accordingly, participants of the present study were then categorised into two groups for statistical analysis: physically active and physically inactive.

\section{Blood collection and biochemical analysis}

Fasting blood samples were collected from each participant early in the morning between 07.00 and 10.00 hours, following an overnight fast, at baseline and month 6 of the intervention period. Fasting venous blood was drawn by an experienced phlebotomist from the antecubital vein into vacutainer tubes containing fluoride oxalate for plasma glucose analysis and vacutainer tube with clot activator and gel for serum separation (Becton Dickinson) for serum lipids (including total cholesterol, 
Table 1. Predictive formulae for the estimation of BMR of Malaysian adults according to age, sex and body weight

\begin{tabular}{lc}
\hline Age group (years) & Formula \\
\hline Male & \\
$18-30$ & 0.0550 (weight in $\mathrm{kg})+2.480$ \\
$30-60$ & 0.0432 (weight in $\mathrm{kg})+3.112$ \\
Female & \\
$18-30$ & 0.0535 (weight in $\mathrm{kg})+1.994$ \\
$30-60$ & 0.0539 (weight in $\mathrm{kg})+2.147$ \\
\hline
\end{tabular}

TAG and HDL-cholesterol), serum insulin and hsCRP analyses. All the aforementioned biochemical analyses were assessed using Abbott Architect CI8200 Automatic System according to manufacturer's instructions. HOMA-IR was calculated as the product of fasting plasma glucose $(\mathrm{mmol} / \mathrm{l})$ and fasting serum insulin $(\mu \mathrm{U} / \mathrm{ml})$ divided by 22.5 according to homoeostatic model assessment ${ }^{(47)}$. LDL-cholesterol was calculated from values of total cholesterol, HDL-cholesterol and TAG using the Friedewald formula: $\quad$ LDL-cholesterol $=$ total cholesterol $-((T A G / 5)+$ HDL-cholesterol) ${ }^{(48)}$.

\section{Measure of dietary adherence}

Dietary adherence was assessed as the difference between participant's respective macronutrient goal as per the assigned diet and their reported dietary intake at the end of the 6-month intervention period. For participants assigned to the intervention diet group, dietary adherence was calculated as the difference between the reported and recommended distribution of percentage energy from protein:fat:carbohydrate, which was 30:30:40, using the 'Mahalanobis distance equation'(49). The equation used to calculate distance from the recommended goal was

$$
\sqrt{\frac{\left(\left(X_{\mathrm{PRO}}-30\right)^{2}+\left(X_{\mathrm{FAT}}-30\right)^{2}+\left(X_{\mathrm{CHO}}-40\right)^{2}\right)}{3}}
$$

where $X_{\mathrm{PRO}}, X_{\mathrm{FAT}}$ and $X_{\mathrm{CHO}}$ were defined as participant's reported percentage energy from protein, fat and carbohydrate, respectively. For participants assigned to the control diet group, dietary adherence was calculated as the difference between the reported and recommended distribution of percentage energy from protein:fat:carbohydrate, which was 15:30:55.

$$
\sqrt{\frac{\left(\left(X_{\mathrm{PRO}}-15\right)^{2}+\left(X_{\mathrm{FAT}}-30\right)^{2}+\left(X_{\mathrm{CHO}}-55\right)^{2}\right)}{3}}
$$

The adherence score measured a degree of deviation from the recommended macronutrient goal. Thus, a lower score indicated better adherence and a higher score indicated poorer adherence.

\section{Power and sample size calculation}

Sample size was computed using the formula $n=\left(2 \mathrm{sD}^{2}\right.$ $\left.\left(Z_{1-\alpha 2}+Z_{1-\beta}\right)^{2}\right) / d^{2}$, according to Charan \& Biswas ${ }^{(50)}$. The primary outcome measure is 'change in body weight'. Assuming an expectation of $10 \%$ reduction in body weight post-intervention, an effect size $(d)$ of $7.6(76-68.4=7.6 \mathrm{~kg}$; with an SD of $\left.11 \cdot 2^{(51)}\right)$ was calculated. To detect this difference with a significance level of $95 \%(1-\alpha 2=1.96)$ and power of $80 \%$ $(1-\beta=0 \cdot 84)$, thirty-four participants were required in each arm of the study. Assuming an attrition rate of $20 \%$, forty-one participants were required in each arm of the study. Thus, the computed sample size is 82 .

\section{Data analysis}

Statistical analysis was performed using the statistical package for social sciences (IBM SPSS statistic, version 22). Data were expressed as means with their standard errors or number (percentage). Log transformation was performed to transform nonnormally distributed data into normally distributed data. The current study was designed to test an approach applicable to primary care and hence the analysis was conducted on an intention-totreat (ITT) basis rather than on compliance to treatment (per protocol). The latest data on anthropometric, blood biochemical and dietary parameters from all participants (completers and noncompleters) was computed for statistical analysis. The independent $t$ test and $\chi^{2}$ test were performed to assess the differences between the Hipcref diet group and control diet group at baseline on continuous variables and categorical variables, respectively.

A two-way mixed ANOVA was performed to assess the effect of treatment group $\times$ time in anthropometric parameters at baseline, month 3 and month 6 between the Hipcref diet group and control diet group on an 'ITT' basis. Adjustment for covariates such as age, sex, physical activity status, smoking status and alcohol consumption was applied. With a significant $F$ test, post hoc pairwise comparison was performed to assess the differences within the treatment groups at different time points. A two-way mixed ANOVA was performed to assess the changes in blood biochemical and dietary parameters at baseline and at month 6 between the Hipcref diet group and control diet group. Adjustment for covariates such as age, sex, physical activity status, smoking status and alcohol consumption was applied. A statistical probability level of $P<0.05$ (twosided) was considered significant.

\section{Results}

A total of 128 participants ( $84 \%$ women) completed the baseline assessment. They were randomly assigned to the Hipcref diet group $(n 65$; female $=54$ and male $=11$ ) or the control diet group ( $n$ 63; female $=54$ and male $=9$ ). Of the initial 128 participants, seven participants dropped out from the Hipcref diet group and eighteen participants dropped out from the control diet group due to job relocation ( $n 9$ ), retirement ( $n 5$ ), accident ( $n$ 2), volunteer withdrawal of consent $(n 5)$ and four were lost to follow up (Fig. 1). Therefore, the study was completed with 103 participants: Hipcref diet group $=58$ participants (female $=47$ and male $=11$ ); control diet group $=45$ participants (female $=41$ and male $=4$ ). There was no significant difference in the general characteristics between the completers and dropouts in the Hipcref diet group (Table 2). However, we found that dropouts in the control diet group had significantly lower age $(P=0 \cdot 017)$, higher body weight $(P=0 \cdot 001)$, higher BMI $(P=0.003)$ and comprised of higher number of smokers compared with the completers. 


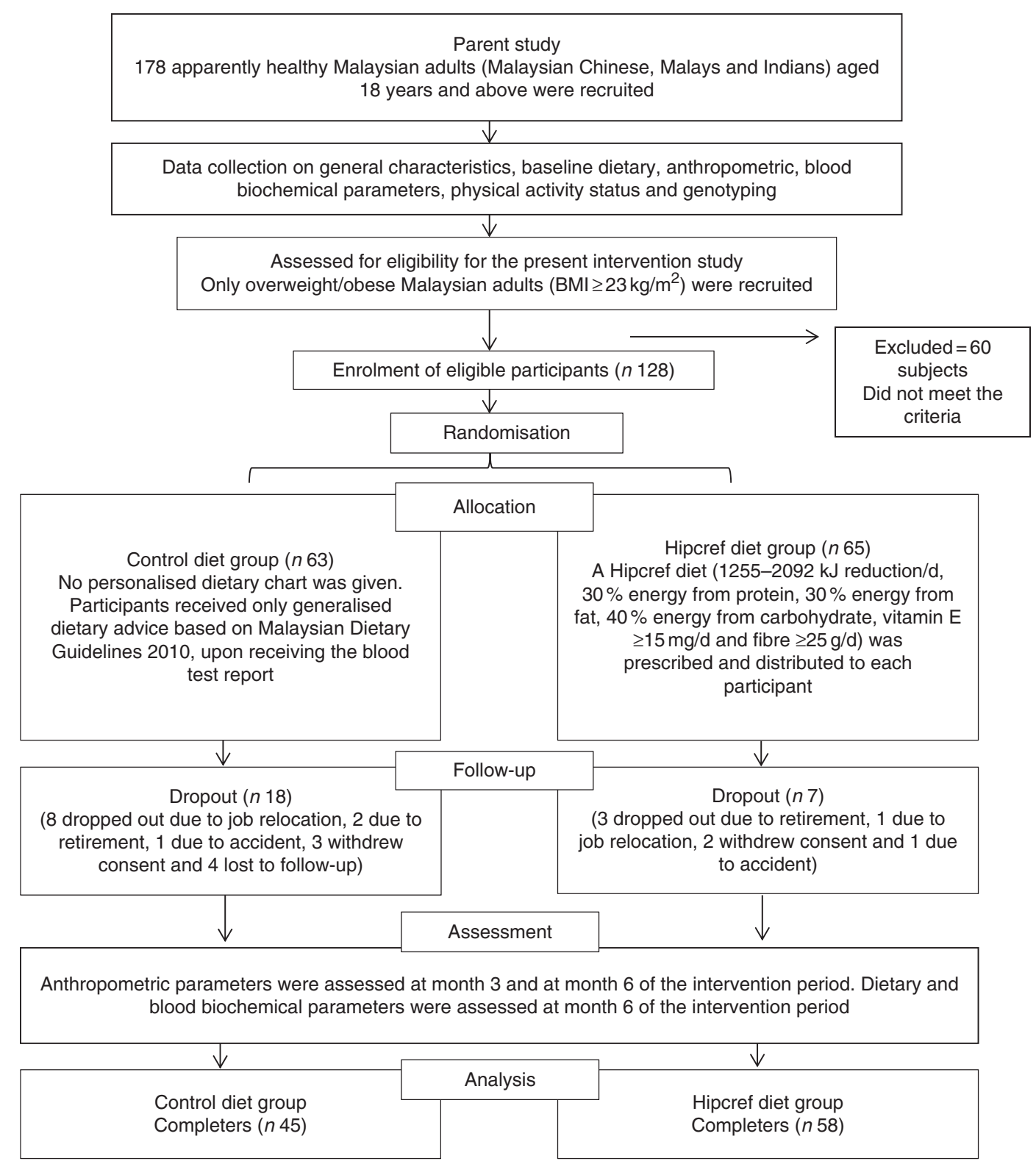

Fig. 1. Flow chart of the intervention study: enrolment, random allocation, follow-up, withdrawal and assessment of the study participants. Hipcref, high-protein, energy-restricted, high vitamin $\mathrm{E}$ and fibre.

The statistical analysis on the comparisons of the general characteristics between the Hipcref diet group and control diet group was conducted on an ITT basis (Table 3). The sex distribution was not significantly different in both the Hipcref diet group and control diet group, females (83v. 86\%) and males (17 v. 14\%) $(P=0.681)$. The mean age (years) in the two arms of the study did not differ statistically (Hipcref diet group: $44 \cdot 8$ (SE 1.3) years and control diet group: 43.1 (SE 1.5) years; $P=0.266$ ). There was no significant difference in the distribution of the three ethnic groups in the two arms of the study $(P=0.996)$. No difference in physical activity status $(P=0.057)$, smoking status $(P=0.219)$ and alcohol consumption status $(P=0.351)$ as well. No significant difference was found in height $(P=0.480)$, body weight $(P=0.530)$ and BMI $(P=0.757)$ between the two groups. No significant difference was found in the frequency of non-vegetarians and vegetarians between the Hipcref diet group (98.5 and $1.5 \%$, respectively) and control diet group (98.4 and $1.6 \%$, respectively) $(P=0.982)$.

\section{Anthropometric parameters at baseline, month 3 and} month 6 comparing high-protein, energy-restricted, highvitamin $E$ and -fibre diet group and control diet group

A two-way mixed ANOVA (Table 4) revealed significant treatment group $\times$ time effect on body weight $(P<0 \cdot 001)$, BMI $(P<0.001)$, WC $(P<0.001)$, WHR $(P=0.001)$, fat mass $(P<0.001)$, fat-free mass $(P=0 \cdot 010)$ and percentage body fat 
Table 2. Differences in the general characteristics between the completers and dropouts in the high-protein, energy-restricted, high-vitamin $E$ and -fibre (Hipcref) diet group and control diet group

(Numbers and percentages; mean values with their standard errors)

\begin{tabular}{|c|c|c|c|c|c|c|c|c|c|c|}
\hline \multirow[b]{3}{*}{ Variables } & \multicolumn{5}{|c|}{ Hipcref diet group ( $n$ 65) } & \multicolumn{5}{|c|}{ Control diet group ( $n$ 63) } \\
\hline & \multicolumn{2}{|c|}{ Completers (n 58) } & \multicolumn{2}{|c|}{ Dropouts (n 7) } & \multirow[b]{2}{*}{$P$} & \multicolumn{2}{|c|}{ Completers (n 45) } & \multicolumn{2}{|c|}{ Dropouts (n 18) } & \multirow[b]{2}{*}{$P$} \\
\hline & $n$ & $\%$ & $n$ & $\%$ & & $n$ & $\%$ & $n$ & $\%$ & \\
\hline Age (years) & & & & & $0 \cdot 151$ & & & & & $0.017^{*} \dagger$ \\
\hline Mean & \multicolumn{2}{|c|}{$44 \cdot 2$} & \multicolumn{2}{|c|}{$49 \cdot 9$} & & \multicolumn{2}{|c|}{$45 \cdot 4$} & \multicolumn{2}{|c|}{37.4} & \\
\hline SE & \multicolumn{2}{|c|}{$1 \cdot 3$} & \multicolumn{2}{|c|}{2.9} & & \multicolumn{2}{|c|}{$1 \cdot 8$} & \multicolumn{2}{|c|}{2.5} & \\
\hline \multicolumn{11}{|l|}{ Sex } \\
\hline Female & 47 & 81 & 7 & 100 & 0.206 & 41 & $91 \cdot 1$ & 13 & $72 \cdot 2$ & $0.053 \ddagger$ \\
\hline Male & 11 & 19 & 0 & & & 4 & 8.9 & 5 & $27 \cdot 8$ & \\
\hline \multicolumn{11}{|l|}{ Ethnicity } \\
\hline Malays & 10 & $17 \cdot 2$ & 2 & 28.6 & 0.232 & 6 & $13 \cdot 3$ & 6 & $33 \cdot 3$ & $0.176 \ddagger$ \\
\hline Chinese & 28 & $48 \cdot 3$ & 1 & $14 \cdot 3$ & & 22 & $48 \cdot 9$ & 6 & $33 \cdot 3$ & \\
\hline Indians & 20 & 34.5 & 4 & $57 \cdot 1$ & & 17 & $37 \cdot 8$ & 6 & $33 \cdot 3$ & \\
\hline \multicolumn{11}{|l|}{ Physical activity status } \\
\hline Physically inactive & 52 & 89.7 & 7 & 100 & 0.372 & 45 & 100 & 17 & 94.4 & $0.111 \ddagger$ \\
\hline Physically active & 6 & $10 \cdot 3$ & 0 & & & 0 & & 1 & $5 \cdot 6$ & \\
\hline \multicolumn{11}{|l|}{ Smoking status } \\
\hline Never & 57 & $98 \cdot 3$ & 7 & 100 & 0.726 & 45 & 100 & 16 & 88.9 & $0.023^{*} \ddagger$ \\
\hline Former & 0 & & 0 & & & 0 & & 0 & & \\
\hline Current & 1 & $1 \cdot 7$ & 0 & & & 0 & & 2 & $11 \cdot 1$ & \\
\hline \multicolumn{11}{|c|}{ Alcohol consumption status } \\
\hline Never & 58 & 100 & 7 & 100 & 1 & 45 & 100 & 16 & $88 \cdot 8$ & $0.076 \ddagger$ \\
\hline Former & 0 & & 0 & & & 0 & & 1 & $5 \cdot 6$ & \\
\hline Current & 0 & & 0 & & & 0 & & 1 & $5 \cdot 6$ & \\
\hline \multicolumn{11}{|l|}{ Dietary preference } \\
\hline Non-vegetarian & 57 & $98 \cdot 3$ & 7 & 100 & 0.726 & 44 & $97 \cdot 8$ & 18 & 100 & $0.524 \ddagger$ \\
\hline Vegetarian & 1 & $1 \cdot 7$ & 0 & & & 1 & $2 \cdot 2$ & 0 & & \\
\hline Height (cm) & & & & & 0.657 & & & & & $0.084 \dagger$ \\
\hline Mean & & & & & & & & & & \\
\hline SE & & & & & & & & & & \\
\hline Weight (kg) & & & & & 0.065 & & & & & $0.001^{*} \dagger$ \\
\hline Mean & & & & & & & & & & \\
\hline SE & & & & & & & & & & \\
\hline BMI $\left(\mathrm{kg} / \mathrm{m}^{2}\right)$ & & & & & 0.082 & & & & & $0.003^{*} \dagger$ \\
\hline Mean & & & & & & & & & & \\
\hline SE & & & & & & & & & & \\
\hline
\end{tabular}

* $P<0.05$ was considered as significant.

$\dagger P$ value based on the independent $t$ test.

$\ddagger P$ value based on the $x^{2}$ test.

$(P<0 \cdot 001)$, even after adjusting for covariates, age, sex, physical activity, smoking and alcohol consumption. Further, pairwise comparisons revealed that the Hipcref diet group had significant reduction in body weight, BMI, WC, fat mass and percentage body fat at month 3 and month 6 compared with the baseline values $(P<0.05)$. However, pairwise comparisons revealed that the control diet group showed significant increase in body weight and BMI at month 3 and month 6 compared with the baseline values $(P<0 \cdot 05)$. Moreover, the control diet group showed significant increase in WC, WHR and fat mass at month 6 compared with the baseline values $(P<0 \cdot 05)$.

Mean differences in responses in blood pressure and blood biochemical parameters at baseline and month 6 between high-protein, energy-restricted, high-vitamin E and-fibre diet group and control diet group

A two-way mixed ANOVA revealed that the Hipcref diet group had significantly higher reduction in fasting insulin $(P<0 \cdot 001)$, HOMA-IR $(P<0.001)$ and hsCRP levels $(P=0.020)$ compared with the control diet group at month 6, even after adjusting for covariates, age, sex, physical activity, smoking and alcohol consumption (Table 5). No significant difference was found in blood pressure, fasting glucose and blood lipid levels between the two groups $(P>0.05)$.

\section{Mean differences in responses in dietary parameters at baseline and month 6 between high-protein, energy-restricted, high-vitamin $E$ and -fibre diet group and control diet group}

Results from a two-way mixed ANOVA revealed that the Hipcref diet group consumed significantly higher percentage energy from protein $(P<0 \cdot 001)$, percentage energy from PUFA $(P=0.009)$, energy-adjusted vitamin E (mg) $(P<0.001)$, energyadjusted fibre $(\mathrm{g})(P<0.001)$ and had lower intake of $\mathrm{TE}$ $(P<0.001)$, percentage energy from fat $(P=0.001)$ and percentage energy from carbohydrate $(P=0.007)$ compared with the control diet group at month 6 , even after adjusting for covariates, age, sex, physical activity, smoking and alcohol consumption (Table 6). 
Table 3. General characteristics between the high-protein, energy-restricted, high-vitamin E and -fibre (Hipcref) diet group and control diet group on an intention-to-treat analysis (Numbers and percentages; mean values with their standard errors)

\begin{tabular}{|c|c|c|c|c|c|}
\hline \multirow[b]{2}{*}{ Variables } & \multicolumn{2}{|c|}{ Hipcref diet group ( $n 65)$} & \multicolumn{2}{|c|}{ Control diet group ( $n$ 63) } & \multirow[b]{2}{*}{$P$} \\
\hline & $n$ & $\%$ & $n$ & $\%$ & \\
\hline Age (years) & & & & & $0.266^{*}$ \\
\hline Mean & \multicolumn{2}{|c|}{44.8} & \multicolumn{2}{|c|}{$43 \cdot 1$} & \\
\hline SE & \multicolumn{2}{|c|}{1.3} & \multicolumn{2}{|c|}{1.5} & \\
\hline Sex & & & & & $0.681 \dagger$ \\
\hline Female & 54 & $83 \cdot 1$ & 54 & $85 \cdot 7$ & \\
\hline Male & 11 & $16 \cdot 9$ & 9 & 14.3 & \\
\hline Ethnicity & & & & & $0.996 \dagger$ \\
\hline Malays & 29 & 44.6 & 28 & 44.5 & \\
\hline Chinese & 24 & $36 \cdot 9$ & 12 & $19 \cdot 0$ & \\
\hline Indians & 12 & 18.5 & 23 & 36.5 & \\
\hline Physical activity status & & & & & $0.057 \dagger$ \\
\hline Physically inactive & 59 & $90 \cdot 8$ & 62 & 98.4 & \\
\hline Physically active & 6 & $9 \cdot 2$ & 1 & 1.6 & \\
\hline Smoking status & & & & & $0.219 \dagger$ \\
\hline Never & 64 & 98.5 & 61 & $96 \cdot 8$ & \\
\hline Former & 1 & 1.5 & 0 & & \\
\hline Current & 0 & & 2 & $3 \cdot 2$ & \\
\hline Alcohol consumption status & & & & & $0.351 \dagger$ \\
\hline Never & 65 & 100 & 61 & $96 \cdot 8$ & \\
\hline Former & 0 & & 1 & 1.6 & \\
\hline Current & 0 & & 1 & 1.6 & \\
\hline Dietary preference & & & & & $0.982 \dagger$ \\
\hline Non-vegetarian & 64 & 98.5 & 62 & 98.4 & \\
\hline Vegetarian & 1 & 1.5 & 1 & 1.6 & \\
\hline Height $(\mathrm{cm})$ & & & & & $0.480^{*}$ \\
\hline Mean & & & & & \\
\hline SE & & & & & \\
\hline Weight (kg) & & & & & $0.530^{*}$ \\
\hline Mean & & & & & \\
\hline SE & & & & & \\
\hline BMI $\left(\mathrm{kg} / \mathrm{m}^{2}\right)$ & & & & & $0.757^{*}$ \\
\hline Mean & & & & & \\
\hline SE & & & & & \\
\hline
\end{tabular}

Dietary adherence score comparing high-protein, energyrestricted, high-vitamin $E$ and -fibre diet group and control diet group

The adherence score for both the Hipcref diet group and the control diet group is presented in Table 7. No significant difference was found in the dietary adherence score between the two groups on a per protocol basis $(P=0.489)$. However, significant difference in adherence score was found between the two groups on an ITT basis. The control diet group had significantly higher score (7.4 (SE 0.8)) compared with the Hipcref diet group (4.6 (SE 0.4)) $(P=0.002)$, suggesting poor dietary adherence compared with the Hipcref diet group.

\section{Discussion}

Despite the large number of weight loss intervention programmes, long-term maintenance of weight loss has been unsuccessful in populations, and regain of lost weight is a common phenomenon ${ }^{(52,53)}$. The majority of earlier weight loss intervention studies targeted energy restriction and reduced carbohydrate or fat intake ${ }^{(54)}$. In the present study, we aimed to develop a dietary strategy for weight management which is easy to adhere to. The prescribed diet was based on habitual food intake and hence was affordable. To the best of our knowledge, this is the first study conducted in overweight and obese Malaysian adults that investigates the effectiveness of a 6-month individualised, energy-restricted diet with high-protein, high-vitamin $\mathrm{E}$ and high-fibre intake. The aim of this study was to investigate the effects of the Hipcref diet on body composition and blood biochemical parameters compared with the generalised dietary instruction for weight loss, at the end of the intervention period. As far as we know, our approach is new for the Malaysian population.

Our findings revealed that overweight and obese Malaysian adults following the Hipcref diet had greater reduction in obesity-related anthropometric parameters (BMI, WC, WHR, fat mass and percentage body fat) and better metabolic health outcomes (fasting insulin, HOMA-IR and hsCRP levels) compared with the generalised dietary instruction on weight loss. Participants following the Hipcref diet had successfully reduced $3.5 \mathrm{~kg}$ of body weight and lost $2.3 \%$ of body fat in 
Table 4. Anthropometric parameters at month 3 and month 6 compared with baseline in the high-protein, energy-restricted, high-vitamin $E$ and -fibre (Hipcref) diet group ( $n$ 65) and control diet group ( $n$ 63)‡§

(Mean values with their standard errors)

\begin{tabular}{|c|c|c|c|c|c|c|c|c|c|}
\hline \multirow[b]{2}{*}{ Variables } & \multirow[b]{2}{*}{ Treatment group } & \multicolumn{2}{|c|}{ Baseline } & \multicolumn{2}{|c|}{ Month 3} & \multicolumn{2}{|c|}{ Month 6} & \multirow{2}{*}{$\begin{array}{c}\text { Overall } P \text { valuell } \\
\text { (treatment group } \times \text { time) }\end{array}$} & \multirow{2}{*}{$\begin{array}{l}\text { Within-treatment group } P \text { value } \\
\text { (baseline and month } 6 \text { ) }\end{array}$} \\
\hline & & Mean & SE & Mean & SE & Mean & SE & & \\
\hline \multirow[t]{2}{*}{ Weight (kg) } & Hipcref diet group & $74 \cdot 2$ & 1.5 & $72 \cdot 0^{*}$ & $1 \cdot 6$ & $70 \cdot 8^{*}$ & 1.6 & $<0.001 \Phi$ & $<0.001 \Phi$ \\
\hline & Control diet group & 73.6 & $2 \cdot 4$ & $74.7^{*}$ & 2.4 & $74.9^{*}$ & $2 \cdot 4$ & & $0.012 \pi$ \\
\hline \multirow[t]{2}{*}{ BMI $\left(\mathrm{kg} / \mathrm{m}^{2}\right)$} & Hipcref diet group & $29 \cdot 6$ & 0.6 & $28 \cdot 2^{*}$ & 0.6 & $28.2^{*}$ & 0.6 & $<0.001 \pi$ & $<0.0019$ \\
\hline & Control diet group & 29.4 & 0.7 & $30.0^{*}$ & 0.7 & $30 \cdot 0^{*}$ & 0.7 & & 0.0079 \\
\hline \multirow[t]{2}{*}{ WC (cm) } & Hipcref diet group & 93.2 & 1.4 & $88.9^{*}$ & 1.6 & $87.0^{*}$ & 1.6 & $<0.001 \Phi$ & $<0.001 \rrbracket$ \\
\hline & Control diet group & 94.5 & 1.7 & $95 \cdot 6$ & 1.7 & $95 \cdot 9^{*}$ & 1.7 & & $0.028 \rrbracket$ \\
\hline \multirow[t]{2}{*}{ WHR } & Hipcref diet group & 0.91 & 0.01 & 0.91 & 0.01 & 0.90 & 0.01 & 0.0019 & $0 \cdot 101$ \\
\hline & Control diet group & 0.92 & 0.01 & 0.93 & 0.01 & $0.94^{*}$ & 0.01 & & $0.028 \rrbracket$ \\
\hline \multirow[t]{2}{*}{ Muscle mass $(\mathrm{kg})$} & Hipcref diet group & 23.8 & 0.6 & 23.5 & $0 \cdot 6$ & 23.5 & 0.6 & 0.113 & 0.079 \\
\hline & Control diet group & 23.0 & 0.7 & $23 \cdot 0$ & 0.7 & $23 \cdot 0$ & 0.7 & & 1.000 \\
\hline \multirow[t]{2}{*}{ Fat mass (kg) } & Hipcref diet group & $30 \cdot 8$ & $1 \cdot 1$ & $29 \cdot 1^{*}$ & $1 \cdot 1$ & $27 \cdot 8^{*}$ & 1.2 & $<0.001 \Phi$ & $<0.001 \Phi$ \\
\hline & Control diet group & 31.5 & 1.5 & $32 \cdot 3$ & 1.5 & $32 \cdot 5^{\star}$ & 1.5 & & 0.0439 \\
\hline \multirow[t]{2}{*}{ Fat-free mass (kg) } & Hipcref diet group & 43.5 & 0.9 & $42 \cdot 7^{\star}$ & 1.0 & $42 \cdot 9$ & 1.0 & 0.010 - & $0 \cdot 100$ \\
\hline & Control diet group & $42 \cdot 1$ & $1 \cdot 1$ & $42 \cdot 5$ & $1 \cdot 2$ & 42.5 & $1 \cdot 2$ & & 1.000 \\
\hline \multirow[t]{2}{*}{ Percentage body fat } & Hipcref diet group & $41 \cdot 1$ & 0.9 & $39.5^{\star}$ & $1 \cdot 1$ & $38.8^{*}$ & 1.0 & $<0.001 \Phi$ & $<0.001 \Phi$ \\
\hline & Control diet group & $42 \cdot 1$ & 0.8 & $42 \cdot 8$ & 0.8 & $42 \cdot 9$ & 0.8 & & 0.228 \\
\hline
\end{tabular}

WC, waist circumference; WHR, waist:hip ratio.

* Significant at $P<0.05$; differences from baseline at month 3, and the same at month 6 .

† Significant at $P<0.05$; differences between baseline and month 6 .

$\ddagger$ Covariates, age, sex, physical activity, smoking and alcohol consumption were adjusted for.

$\S$ Further, pairwise comparisons were performed to assess the difference at month 3 and month 6 compared with baseline values within the treatment group.

II A two-way mixed ANOVA was performed to assess the effect of treatment group $\times$ time in anthropometric parameters at month 3 and month 6 between the Hipcref diet group and the control diet group.

II $P<0.05$ was considered significant.

6 months, which translated to a reduction of $0.6 \mathrm{~kg}$ of body weight and $0.4 \%$ of body fat per month. The beneficial effect of the Hipcref diet on obesity-related anthropometric parameters (e.g. BMI, WC, fat mass and percentage body fat) was observed at month 3 and was maintained at month 6. Insulin sensitivity improved significantly in the participants following the Hipcref diet as reflected in the reduced fasting insulin levels and reduced HOMA-IR. Baseline fasting blood glucose levels in the Hipcref diet group were below the diagnostic cutoff $(5.6 \mathrm{mmol} / \mathrm{l})^{(55)}$ defining the metabolic syndrome, and did not reduce after intervention, suggesting that the intervention diet resulted in weight loss and improvement in insulin sensitivity without leading to hypoglycaemia.

Individuals following MDG 2010 dietary guidelines (control diet group) showed opposite effects. They had significant increase in obesity-related anthropometric parameters (e.g. BMI, WC, fat mass and percentage body fat), HOMA-IR and hsCRP levels after 6 months. These results suggest that traditional dietary counselling for weight management based on MDG 2010, National Coordinating Committee for Food and Nutrition $(\mathrm{NCCFN})^{(56)}$ (no more than $6276 \mathrm{~kJ} / \mathrm{d}$ with a macronutrient composition - approximately 10-15\% energy from protein, 20$30 \%$ energy from fat and 55-70\% energy from carbohydrate) seem to be ineffective in promoting weight loss in overweight and obese Malaysian adults.

\section{High attrition rate in control diet group}

Our findings revealed that the Hipcref diet group had better adherence score compared with the control diet group (Table 7). There was relatively higher attrition rate in the control diet group. This may be because of demotivation in the latter individuals to pursue the programme due to failure to lose weight. Our results revealed that the dropouts in the control diet group were younger, had significantly higher BMI and comprised higher number of smokers compared with the completers (Table 2).

\section{Intervention diet - energy restriction}

Our findings revealed significant reduction in TE intake in individuals following the Hipcref diet (an average reduction of $422 \mathrm{kcal} / \mathrm{d}$ ). Portion control is key to managing weight; however, requesting people simply to 'eat less' may not be the best approach. Smaller portions of high-energy-dense food may disproportionately increase energy intake compared with consumption of low-energy foods ${ }^{(24)}$. Liquid meal replacements and solid pre-portioned foods for weight loss and weight loss maintenance may have been successful in weight loss ${ }^{(14)}$, but it is doubtful whether such artificial diets lead to better understanding of individual portions during meal times post-intervention. Under real-life situations, consumers do not retain the motivation to continue with such foods that do not relate to the cereals, fruits, vegetables, egg or meat that they eat habitually. As part of the intervention process, counselling was provided to the Hipcref diet group on choosing portions that were charted to the participants, using household utensils (scales, plates, cups and spoons) and portion size photographs. We envisaged that this support would lead to improved understanding of the portions consumed and the corresponding energetic value.

With respect to blood biochemical parameters, our results revealed significant reduction in hsCRP and HOMA-IR with the 
Table 5. Responses in blood pressure and blood biochemical parameters at month 6 compared with baseline in the high-protein, energy-restricted, highvitamin $\mathrm{E}$ and -fibre (Hipcref) diet group $(n 65)$ and control diet group $(n 63) \dagger \ddagger$

(Mean values with their standard errors)

\begin{tabular}{|c|c|c|c|c|c|c|c|c|}
\hline \multirow[b]{2}{*}{ Variables } & \multirow[b]{2}{*}{ Treatment group } & \multicolumn{2}{|c|}{ Baseline } & \multicolumn{2}{|c|}{ Month 6} & \multicolumn{2}{|c|}{ Changes } & \multirow[b]{2}{*}{$P$} \\
\hline & & Mean & SE & Mean & SE & Mean & SE & \\
\hline \multirow[t]{2}{*}{ Systolic blood pressure (mmHg) } & Hipcref diet group & 123.9 & 1.8 & $118 \cdot 6$ & 1.8 & $-5 \cdot 3$ & 1.5 & 0.168 \\
\hline & Control diet group & 121.5 & 1.9 & $119 \cdot 2$ & 1.9 & $-2 \cdot 3$ & 1.0 & \\
\hline \multirow[t]{2}{*}{ Diastolic blood pressure $(\mathrm{mmHg})$} & Hipcref diet group & $82 \cdot 4$ & 1.4 & $78 \cdot 1$ & 1.4 & $-4 \cdot 3$ & $1 \cdot 1$ & 0.288 \\
\hline & Control diet group & 79.4 & $1 \cdot 1$ & $77 \cdot 2$ & $1 \cdot 2$ & $-2 \cdot 2$ & 0.9 & \\
\hline \multirow[t]{2}{*}{ Pulse rate $(\mathrm{bpm})$} & Hipcref diet group & $77 \cdot 2$ & 1.4 & $72 \cdot 8$ & 1.6 & $-4 \cdot 4$ & 1.4 & 0.624 \\
\hline & Control diet group & $75 \cdot 7$ & 1.4 & $72 \cdot 3$ & 1.4 & -3.4 & $1 \cdot 1$ & \\
\hline \multirow[t]{2}{*}{ Fasting glucose $(\mathrm{mmol} / \mathrm{l})$} & Hipcref diet group & $5 \cdot 2$ & 0.2 & $5 \cdot 1$ & 0.2 & -0.02 & 0.2 & 0.448 \\
\hline & Control diet group & $5 \cdot 3$ & 0.3 & 5.4 & 0.3 & 0.1 & 0.2 & \\
\hline \multirow[t]{2}{*}{ Fasting insulin $(\mu \mathrm{U} / \mathrm{ml})$} & Hipcref diet group & 11.8 & 1.5 & $8 \cdot 3$ & 0.7 & $-3 \cdot 4$ & $1 \cdot 2$ & $<0.001^{*}$ \\
\hline & Control diet group & 8.4 & 0.8 & $12 \cdot 8$ & $1 \cdot 3$ & 4.5 & 0.8 & \\
\hline \multirow[t]{2}{*}{ HOMA-IR } & Hipcref diet group & $3 \cdot 0$ & 0.5 & $2 \cdot 0$ & 0.2 & $-1 \cdot 0$ & 0.4 & $<0.001^{*}$ \\
\hline & Control diet group & $2 \cdot 0$ & 0.2 & 3.3 & 0.4 & 1.3 & 0.3 & \\
\hline \multirow[t]{2}{*}{ Total cholesterol (mmol/l) } & Hipcref diet group & 5.5 & $0 \cdot 1$ & $5 \cdot 3$ & 0.1 & $-0 \cdot 2$ & 0.1 & 0.461 \\
\hline & Control diet group & 5.5 & $0 \cdot 1$ & 5.4 & 0.1 & -0.1 & 0.1 & \\
\hline \multirow[t]{2}{*}{ TAG (mmol/l) } & Hipcref diet group & 1.5 & 0.1 & 1.5 & 0.1 & 0.01 & 0.1 & 0.919 \\
\hline & Control diet group & 1.3 & 0.1 & 1.4 & 0.1 & 0.1 & 0.1 & \\
\hline \multirow[t]{2}{*}{ HDL-cholesterol (mmol/l) } & Hipcref diet group & 1.5 & 0.1 & 1.4 & 0.1 & $-0 \cdot 1$ & 0.1 & 0.624 \\
\hline & Control diet group & 1.6 & 0.1 & 1.4 & 0.1 & -0.1 & 0.1 & \\
\hline \multirow[t]{2}{*}{ LDL-cholesterol (mmol/l) } & Hipcref diet group & 3.3 & 0.1 & $3 \cdot 2$ & 0.1 & -0.1 & 0.1 & 0.429 \\
\hline & Control diet group & 3.4 & $0 \cdot 1$ & $3 \cdot 3$ & 0.1 & -0.1 & 0.1 & \\
\hline \multirow[t]{2}{*}{ Total cholesterol:HDL-cholesterol } & Hipcref diet group & 3.8 & 0.1 & $4 \cdot 0$ & 0.1 & 0.2 & 0.1 & 0.933 \\
\hline & Control diet group & 3.7 & 0.1 & 4.0 & 0.1 & 0.3 & 0.1 & \\
\hline \multirow[t]{2}{*}{ hsCRP (mg/l) } & Hipcref diet group & $6 \cdot 1$ & 1.0 & 4.0 & 0.6 & $-1 \cdot 4$ & 0.6 & $0.020^{\star}$ \\
\hline & Control diet group & $5 \cdot 3$ & 1.0 & $5 \cdot 7$ & 0.9 & 0.3 & 0.4 & \\
\hline
\end{tabular}

HOMA-IR, homoeostatic model assessment-insulin resistance; hsCRP, high-sensitivity C-reactive protein.

${ }^{*} P<0.05$ was considered as significant.

† A two-way mixed ANOVA was performed to assess the effect of treatment group $\times$ time in blood pressure and blood biochemical parameters between the Hipcref diet group and control diet group.

‡ Covariates, age, sex, physical activity, smoking and alcohol consumption were adjusted for.

Hipcref diet. hsCRP is known to be the best systemic marker for inflammation and it is a strong independent predictor of future cardiovascular events ${ }^{(57)}$. It has been demonstrated that increase in hsCRP levels was highly associated with increased adipose tissue. Adipose tissue is involved in the regulation and production of inflammatory cytokines that induce the production of hsCRP ${ }^{(58)}$. Therefore, a reduction in the excess body fat stores can significantly reduce the inflammatory state ${ }^{(59)}$. A systematic review reported that reduction in hsCRP levels may be due to the consequence of weight loss following a moderate reduction in energy intake ${ }^{(60)}$. Previous studies have reported that energy restriction was a significant factor in improving glycaemic control and insulin sensitivity with weight loss ${ }^{(61)}$. In our participants, favourable effect on the above biochemical parameters in individuals on the Hipcref diet may due to the energy restriction and reduction in body fat mass.

\section{Intervention diet - higher intake of protein}

High-protein diets promote weight loss, reduce abdominal obesity, reduce TAG levels, and improve glucose metabolism ${ }^{(62-65)}$. We envisaged that higher protein intake could prevent loss of muscle mass as the participants lost weight through energy reduction. Johnston et al. ${ }^{(66)}$ reported that a high-protein diet with modest energy restriction was effective in reducing HOMA-IR in healthy adults compared with a lower-protein, standard diet, in the US population. Conflicting theories have been reported by other studies. Wycherley et al. ${ }^{(67)}$ reported that high-protein and standard-protein diets resulted in similar weight loss and reduction in HOMA-IR. These investigators concluded that reduction in body weight was the factor in improving insulin sensitivity compared with the quantity of dietary protein.

Several studies have investigated the effect of high-protein diets on hsCRP ${ }^{(21,22,68)}$. Gulati et al. ${ }^{(21)}$ reported that a highprotein diet (29\% PRO, 24\% FAT and $47 \% \mathrm{CHO}$ ) was found to be effective in reducing hsCRP levels compared with the control diet group (15\% PRO, 25\% FAT and 60\% CHO) in an Indian population. Contrary to that, Azadbakht et al. ${ }^{(22)}$ and Noakes et $a l .{ }^{(68)}$ reported that hsCRP level reduced, with weight loss independent of dietary protein content, in an Iranian population.

In our participants, perhaps the positive impact on insulin sensitivity was due to the combined effect of both energy restriction and high protein intake.

\section{Macronutrient intake and intervention diet}

Participants in the Hipcref diet group had significantly lower consumption of TE intake, percentage energy from fat and percentage energy from carbohydrate and significantly higher intake of percentage energy from protein, PUFA and fibre compared with the control diet group after 6 months of dietary intervention. 
Table 6. Responses in dietary parameters at month 6 compared with baseline in the high-protein, energy-restricted, high-vitamin $E$ and -fibre (Hipcref) diet group ( $n$ 65) and control diet group ( $n$ 63)†‡

(Mean values with their standard errors)

\begin{tabular}{|c|c|c|c|c|c|c|c|c|}
\hline \multirow[b]{2}{*}{ Dietary parameters } & \multirow[b]{2}{*}{ Treatment group } & \multicolumn{2}{|c|}{ Baseline } & \multicolumn{2}{|c|}{ Month 6} & \multicolumn{2}{|c|}{ Changes } & \multirow[b]{2}{*}{$P$} \\
\hline & & Mean & SE & Mean & SE & Mean & SE & \\
\hline \multirow[t]{2}{*}{ Total energy intake (kJ) } & Hipcref diet group & 8456 & 197 & 6690 & 130 & -1766 & 159 & $<0.001^{*}$ \\
\hline & Control diet group & 8351 & 159 & 8217 & 151 & -134 & 75 & \\
\hline \multirow[t]{2}{*}{ Protein intake $(\mathrm{g})$} & Hipcref diet group & 75.5 & 3.0 & 108.0 & $2 \cdot 8$ & 32.5 & 3.4 & $<0.001^{*}$ \\
\hline & Control diet group & $74 \cdot 1$ & $2 \cdot 9$ & 7.54 & $2 \cdot 2$ & 1.3 & $2 \cdot 3$ & \\
\hline \multirow[t]{2}{*}{ Fat intake $(\mathrm{g})$} & Hipcref diet group & $84 \cdot 7$ & $2 \cdot 8$ & $57 \cdot 6$ & 1.8 & $-27 \cdot 1$ & $2 \cdot 7$ & $<0.001^{*}$ \\
\hline & Control diet group & $80 \cdot 8$ & 2.5 & $75 \cdot 2$ & $2 \cdot 4$ & $-5 \cdot 7$ & 1.9 & \\
\hline \multirow[t]{2}{*}{ Carbohydrate intake $(\mathrm{g})$} & Hipcref diet group & 251.9 & $8 \cdot 7$ & $175 \cdot 2$ & 4.7 & $-76 \cdot 8$ & 7.4 & $<0.001^{*}$ \\
\hline & Control diet group & $255 \cdot 6$ & $7 \cdot 3$ & 265.8 & $6 \cdot 0$ & $10 \cdot 2$ & 4.7 & \\
\hline \multirow[t]{2}{*}{ Percentage energy from protein (\%) } & Hipcref diet group & 14.8 & 0.5 & $27 \cdot 2$ & 0.6 & $12 \cdot 4$ & 0.7 & $<0.001^{*}$ \\
\hline & Control diet group & $14 \cdot 8$ & 0.5 & $15 \cdot 3$ & 0.3 & 0.5 & 0.5 & \\
\hline \multirow{2}{*}{ Percentage energy from fat (\%) } & Hipcref diet group & 37.4 & 0.9 & $32 \cdot 3$ & 0.7 & $-5 \cdot 1$ & 0.9 & $0.001^{*}$ \\
\hline & Control diet group & $36 \cdot 0$ & 0.9 & 37.5 & $1 \cdot 1$ & -1.9 & 0.7 & \\
\hline \multirow[t]{2}{*}{ Percentage energy from carbohydrate (\%) } & Hipcref diet group & $46 \cdot 2$ & $1 \cdot 1$ & $43 \cdot 3$ & 0.6 & $-2 \cdot 9$ & $1 \cdot 0$ & $0.007^{\star}$ \\
\hline & Control diet group & $47 \cdot 9$ & 1.0 & 50.0 & 1.4 & $5 \cdot 6$ & 1.0 & \\
\hline \multirow[t]{2}{*}{ SFA ( $\%$ of TE) } & Hipcref diet group & $8 \cdot 1$ & 0.5 & $8 \cdot 2$ & 0.3 & 0.1 & 0.5 & 0.070 \\
\hline & Control diet group & 7.5 & 0.5 & 9.0 & 0.4 & 1.5 & 0.5 & \\
\hline \multirow[t]{2}{*}{ MUFA (\% of TE) } & Hipcref diet group & 11.4 & $0 \cdot 6$ & $10 \cdot 6$ & 0.3 & $-0 \cdot 8$ & 0.5 & 0.562 \\
\hline & Control diet group & 11.0 & 0.5 & $10 \cdot 6$ & 0.4 & -0.3 & 0.5 & \\
\hline \multirow[t]{2}{*}{ PUFA (\% of TE) } & Hipcref diet group & $6 \cdot 6$ & 0.4 & $8 \cdot 1$ & 0.3 & 1.4 & 0.4 & $0.009^{\star}$ \\
\hline & Control diet group & $6 \cdot 3$ & 0.4 & 6.5 & 0.3 & 0.2 & 0.4 & \\
\hline \multirow[t]{2}{*}{ TFA (\% TE) } & Hipcref diet group & $0 \cdot 1$ & 0.1 & 0.1 & $0 \cdot 1$ & $-\S$ & & 0.058 \\
\hline & Control diet group & $0 \cdot 1$ & $0 \cdot 1$ & 0.2 & $0 \cdot 1$ & $-\S$ & & \\
\hline \multirow[t]{2}{*}{ Energy-adjusted fibre intake (g) } & Hipcref diet group & $6 \cdot 3$ & 0.4 & $13 \cdot 5$ & 0.5 & $7 \cdot 2$ & 0.5 & $<0.001^{*}$ \\
\hline & Control diet group & 5.5 & 0.4 & $9 \cdot 0$ & 0.5 & 3.5 & 0.5 & \\
\hline \multirow[t]{2}{*}{ Energy-adjusted vitamin E intake (mg) } & Hipcref diet group & $5 \cdot 7$ & 0.4 & $8 \cdot 0$ & 0.2 & $2 \cdot 3$ & 0.4 & $<0.001^{*}$ \\
\hline & Control diet group & 5.9 & 0.4 & $6 \cdot 4$ & 0.3 & 0.5 & 0.4 & \\
\hline
\end{tabular}

TFA, trans-fatty acids, TE, total energy.

${ }^{*} P<0.05$ was considered as significant.

† A two-way mixed ANOVA was performed to assess the effect of treatment group $x$ time in blood pressure and blood biochemical parameters between the Hipcref diet group and control diet group.

‡ Covariates, age, sex, physical activity, smoking and alcohol consumption were adjusted for.

$\S$ No change.

Table 7. Adherence score between the high-protein, energy-restricted, high-vitamin E and -fibre (Hipcref) diet group and control diet group (Mean values with their standard errors)

\begin{tabular}{|c|c|c|c|c|c|c|}
\hline \multirow[b]{2}{*}{ Adherence score } & \multicolumn{3}{|c|}{ Per protocol analysis $†$} & \multicolumn{3}{|c|}{ Intention-to-treat analysis $†$} \\
\hline & Hipcref diet group ( $n$ 58) & Control diet group ( $n$ 45) & $P$ & Hipcref diet group ( $n$ 65) & Control diet group ( $n$ 63) & $P$ \\
\hline Mean & 3.8 & $4 \cdot 1$ & 0.489 & 4.6 & $7 \cdot 4$ & $0.002^{*}$ \\
\hline SE & 0.2 & 0.4 & & 0.4 & 0.8 & \\
\hline Minimum & $1 \cdot 1$ & 1.5 & - & 1.1 & 1.5 & \\
\hline Maximum & $8 \cdot 2$ & 11.3 & - & $16 \cdot 4$ & $22 \cdot 7$ & \\
\hline
\end{tabular}

${ }^{*} P<0.05$ was considered as significant.

$\dagger$ The independent $t$ test was performed to assess the difference in adherence score between the Hipcref diet group and control diet group.

Despite widespread consensus that a reduced intake of saturated fat lowers CVD risk, the optimal type of macronutrient (protein, unsaturated fat or carbohydrate) that should replace saturated fat is uncertain ${ }^{(69)}$. Many past studies have focused on fat consumption and the metabolic syndrome ${ }^{(70,71)}$. In particular, the consumption of saturated fat was believed to influence insulin resistance and CVD by increasing serum LDL-cholesterol levels ${ }^{(72)}$. In recent years, there has been an increasing interest in the effect of carbohydrate on metabolic disease. In the past, it was not considered a concern if 55-65\% of the TE was sourced from carbohydrate-rich foods. However, recently there is concern that excessive intake of carbohydrates, particularly refined carbohydrates, may contribute to metabolic diseases ${ }^{(73)}$. High- carbohydrate consumption has been reported to increase serum TAG and lower HDL-cholesterol and lead to the metabolic syndrome $^{(74)}$. Further, excess carbohydrates are converted to TAG, and the correlation between elevated serum TAG levels and CVD cannot be disputed $^{(75)}$. Lower consumption of carbohydrate and increased consumption of protein may, in fact, be the most effective way to reduce serum TAG levels.

In our study, in the Hipcref diet group, we observed a reduction in total cholesterol and LDL-cholesterol levels from baseline although these reductions did not reach statistical significance. No change in TAG levels from baseline was found in the participants following the Hipcref diet, and the TAG levels were lower than the diagnostic cut-off defining the 
metabolic syndrome $\left(1.7 \mathrm{mmol} / \mathrm{l}^{(55)}\right)$. There was a small reduction in HDL-cholesterol level in the Hipcref diet group, this difference from baseline did not reach statistical significance and was above the diagnostic cut off defining the metabolic syndrome $\left(1.03 \mathrm{mmol} / \mathrm{l}\right.$ for male; $1.29 \mathrm{~mol} / \mathrm{l}$ for female $\left.{ }^{(55)}\right)$. These results may be explained by the food sources selected for the Hipcref diet participants. The food sources to increase protein intake in the present study were mainly animal proteins. Animal food sources are known to increase saturated fat intake. A systematic review reported that soya protein (with isoflavones) or other plant proteins (pea and lupine protein, wheat gluten) had greater decrease in total cholesterol and LDL-cholesterol levels compared with animal-sourced protein ${ }^{(76)}$. Diets that induce negative energy balance continue to be the cornerstone of weight management. However, long-term volitional reduction in energy intake is challenging. With transformation of Malaysia's economy in the recent decades, the food consumption pattern of the population has shifted from that of a traditional cereal- and legume-based one to that which is rich in meat and meat products ${ }^{(77)}$. Animal products not only provide high-quality protein but also are important sources of essential micronutrients ( $\mathrm{Fe}, \mathrm{Zn}$ and vitamin $\mathrm{A}$ ). To maximise outcome, our Hipcref diet sourced protein mainly from food of animal origin, for example, milk and milk products, egg, fish and chicken, but not red meat.

Two major goals of dietary recommendations are to lower blood pressure and improve serum lipids, two of the primary determinants of CVD risk. Early research documented that the DASH diets (carbohydrate-rich diet that emphasises fruits, vegetables, and low-fat dairy products) reduced blood pressure in study subjects ${ }^{(78)}$. In addition to lowering blood pressure, the DASH diet lowered total cholesterol and LDL-cholesterol levels ${ }^{(79)}$. It is uncertain whether partial replacement of carbohydrate with either unsaturated fat or protein can improve blood pressure and lipid profile ${ }^{(79)}$. In OmniHeart randomised trial, a diet that partially replaced carbohydrates with protein, about half from plant sources, lowered blood pressure, LDL-cholesterol levels, and TAG levels as well as HDL-cholesterol levels among adults with prehypertension or stage 1 hypertension ${ }^{(80)}$. A diet that partially replaced carbohydrates with unsaturated fat, predominantly monounsaturated fat, lowered blood pressure and TAG levels and increased HDL-cholesterol levels but had no significant effect on LDL-cholesterol levels.

The Hipcref diet contributed to $32 \%$ energy from fat of which $8 \%$ of TE was from SFA, $11 \%$ of TE from MUFA, $8 \%$ of TE from PUFA and $0.1 \%$ of TE from TFA. These changes from the baseline were within the favourable range of the recommended guidelines ${ }^{(36)}$. The Hipcref diet was successful in increasing the PUFA intake from $6 \%$ of TE to $8 \%$ of TE, which is on the higher range of the recommendation (4-8\% of $\mathrm{TE})^{(36)}$. We report that moderate energy restriction (average reduction of $1766 \mathrm{~kJ} / \mathrm{d}$ ), carbohydrate restriction ( $43 \%$ energy from carbohydrate; $175 \mathrm{~g} / \mathrm{d}$ ) and higher protein intake (an average of $27 \%$ energy from protein; $108 \mathrm{~g} / \mathrm{d}$ ), with fat intake within the NCCFN guidelines have been successful in managing weight in our Malaysian adult participants.

\section{Intervention diet $-\geq 15 \mathrm{mg} / \mathrm{d}$ vitamin $E$}

Dietary micronutrients, especially with anti-inflammatory and anti-oxidant properties are known to have beneficial effects on cardiovascular outcome ${ }^{(81)}$. Vitamin $\mathrm{E}$ is a micronutrient with anti-oxidant and immune-modulating properties, which can reduce oxidative stress and inflammation ${ }^{(82)}$. A study by Devaraj et al. ${ }^{(83)}$ demonstrated that the combination of $\alpha$ - and $\gamma$-tocopherol supplementation showed beneficial effect on markers of inflammation in patients suffering from the metabolic syndrome, suggesting the potential of vitamin $\mathrm{E}$ in ameliorating oxidative stress and inflammation in such patients. A significant inverse association of vitamin $\mathrm{E}$ and hsCRP has been demonstrated in other studies ${ }^{(32,33)}$. In our study, the intake of vitamin $\mathrm{E}$ in both the Hipcref diet group and control diet group met the Malaysian dietary recommendations $(7.5 \mathrm{mg} / \mathrm{d}$ for women and $10 \mathrm{mg} / \mathrm{d}$ for men). However, reduction in hsCRP levels was only observed in the Hipcref diet group.

Previous studies demonstrated that vitamin E supplementation $(900 \mathrm{mg} / \mathrm{d}$ for 4 months) reduced oxidative stress and improved insulin action in healthy and non-insulin-dependent diabetic patients ${ }^{(84)}$. Manning et al. ${ }^{(85)}$ reported that overweight individuals supplemented with high-dose vitamin E (800 IU of vitamin $\mathrm{E} / \mathrm{d}$ for 3 months and $1200 \mathrm{IU}$ for further 3 months) improved insulin action and decreased plasma fasting insulin and glucose levels by reducing cellular oxidative stress, altering membrane properties and decreasing inflammatory activity. Therefore, the beneficial effect of the Hipcref diet on metabolic parameters in our study participants may be due to higher vitamin $\mathrm{E}$ intake.

\section{Intervention diet - $\geq 25 \mathrm{~g} / \mathrm{d}$ dietary fibre}

A review of studies examining the effects of fibre on body weight found that higher dietary fibre intake was associated with increased satiety and decreased hunger ${ }^{(86)}$. Large prospective cohort studies consistently reported significant associations between high dietary fibre intake $(>25 \mathrm{~g} / \mathrm{d}$ in women and $>38 \mathrm{~g} / \mathrm{d}$ in men) and reduced risk of developing type 2 diabetes (T2D) $(20-30 \% \text { of reduced risk })^{(87)}$. The proposed mechanisms for this relationship remain unclear, but the type of fibre may play a role. In the gut, certain soluble fibres which form a viscous gel matrix is believed to slow gastric emptying and lead to a greater feeling of fullness ${ }^{(88)}$. Soluble fibres slow absorption of glucose further in the small intestine and lead to lower postprandial glycaemic and insulinaemic responses ${ }^{(89)}$. Therefore, high-soluble fibres may contribute to the improvement in glycaemic control and insulin sensitivity. Moreover, in both the cross-sectional and longitudinal analyses, Ma et al. ${ }^{(90)}$ reported that fibre intake was protective against high hsCRP levels. It was suggested that dietary fibre decreases lipid oxidation, which in turn is associated with decreased inflammation $^{(91)}$. Therefore, we report that the beneficial effect on cardio-metabolic parameters in our Hipcref diet group may be due to their higher fibre intake.

\section{Strengths and limitations}

Participant allocation to the two treatment groups (Hipcref diet and control) was based on a structured randomisation procedure as described earlier. This is a strength of the study. The dietary intervention is novel, practical and easily adoptable in 
day-to-day life. This dietary intervention strategy could be readily tested in primary care services with minimal cost. Our intervention programme did not include any physical activity regimens, that is, dietary modifications alone caused positive changes in anthropometric and metabolic parameters in the intervention group. The study participants represent the three major ethnic groups of Malaysia. This study has tested a dietary strategy that included ethnicity-specific food preferences and popular traditional recipes practiced. The study has successfully proved that simple modification of traditional recipes can bring a modest change in body composition and metabolic health.

There are some limitations to the present study. There was relatively higher attrition rate in the control diet group compared to the Hipcref diet group. This may be due to demotivation to pursue the programme because of failure to lose weight. However, if we assume that the non-completers in the control diet group lost less weight compared with the completers, our estimate of treatment effect would remain unaffected. In other words, it is unlikely that the missing data would have changed our main results from positive to negative. The use of a single $24 \mathrm{~h}$ recall at baseline and at the end of treatment is a limitation of this study. More frequent collection of dietary intake may have provided a more precise representation of actual dietary intake. Body composition was assessed using bioelectrical impedance analysis (BIA). Many factors such as the food and fluid intake, environment, ethnicity and phase of menstrual cycle affect BIA estimates. This is a major limitation of this study. It is understandable that individuals motivated to lose weight participated in the present study willingly. Therefore, the Hipcref diet should be tested in other geographical locations and population groups to assess its efficacy in managing body weight in the Malaysian population at large. As per the dietary strategy of this study, energy restriction, higher protein, PUFA, vitamin $\mathrm{E}$ and dietary fibre intake had a combined effect on the success of the intervention diet. We cannot attribute the success of the Hipcref diet to any one of the latter dietary components.

\section{Conclusion}

Participants in the Hipcref diet group lost $3.5 \mathrm{~kg}$ of body weight and $2 \cdot 6 \%$ of body fat in 6 months, which translated to a reduction of $0.6 \mathrm{~kg}$ of body weight and $0.4 \%$ of body fat per month. Significant reduction was achieved in HOMA-IR and hsCRP levels. Although not significant, small reductions were achieved in total cholesterol and LDL-cholesterol levels. In comparison, such positive effects were not observed in the control diet group. Our results suggest that the Hipcref diet contributed to favourable outcomes in obesity-related anthropometric and metabolic parameters, compared with the MDG 2010 guidelines. The comparison between the post-intervention dietary intake of both groups revealed a significant difference in the intake of the following nutrients per $d$. Participants on the Hipcref diet had reduced energy intake, higher percentage energy from protein, lower percentage energy from fat, lower percentage energy from carbohydrate, higher percentage energy from PUFA, higher vitamin E and fibre intake (Table 6) compared with the control diet group. We opine that the success of the Hipcref diet may be due to the combined effect of the above nutrient composition of the Hipcref diet. Dietary guidelines by MDG 2010 (macronutrient composition approximately $10-15 \%$ energy from protein, $20-30 \%$ energy from fat and $55-70 \%$ energy from carbohydrate) is applicable to healthy Malaysians with healthy BMI. However, for overweight and obese Malaysian adults, we recommend the Hipcref diet for successful weight management and favourable metabolic health. Further, we emphasise that personal dietary preferences should be considered as an important factor when developing strategies for weight management in any population.

\section{Acknowledgements}

The authors would like to express their gratitude to the participants of the study for their time and co-operation. The authors gratefully acknowledge the contribution of Dr Farahnaz Amini for her support of this study. The authors are thankful to Ms Nadia Rajaram for her advice on statistical analysis. The authors thank Ms Nurdiana Binti Haji Zainol Abidin and Ms Leh Hui Eng for their assistance in data collection. The authors also thank the staff of the Diagnostic Center for their assistance with the blood analysis.

The study was funded by internal grants from UNM (UNHB0008)

S. R. M. designed the study, supervised and conducted data collection. P. Y. T. collected data, captured data and performed statistical analysis on the data under the supervision of S. R. M. P. Y. T. and S. R. M. wrote the paper. Both the authors read and approved the final manuscript.

P. Y. T. and S. R. M. declare no conflict of interest.

\section{Supplementary material}

For supplementary material/s referred to in this article, please visit https://doi.org/10.1017/S0007114519000345

\section{References}

1. Upadhyay J, Farr O, Perakakis N, et al. (2018) Obesity as a Disease. Med Clin North Am 102, 13-33.

2. Finer N (2015) Medical consequences of obesity. Medicine $\mathbf{4 3}$, 88-93.

3. Institute for Public Health, Ministry of Health (Malaysia) (2015) National Health \& Morbidity Survey (NHMS) Volume II - Noncommunicable Diseases \& Other Healh Problems. Malaysia: Ministry of Health.

4. Tan AK, Dunn RA, Samad MI, et al. (2011) Sociodemographic and health-lifestyle determinants of obesity risks in Malaysia. Asia Pac J Public Health 23, 192-202.

5. Brown JD, Buscemi J, Milsom V, et al. (2016) Effects on cardiovascular risk factors of weight losses limited to $5-10 \%$. Transl Behav Med 6, 339-346.

6. Wing RR, Lang W, Wadden TA, et al. (2011) Benefits of modest weight loss in improving cardiovascular risk factors in overweight and obese individuals with type 2 diabetes. Diabetes Care 34, 1481-1486.

7. Goodpaster BH, Kelley DE, Wing RR, et al. (1999) Effects of weight loss on regional fat distribution and insulin sensitivity in obesity. Diabetes 48, 839-847. 
8. Pascale RW, Wing RR, Blair EH, et al. (1992) The effect of weight loss on change in waist-to-hip ratio in patients with type II diabetes. Int J Obes Relat Metab Disord 16, 59-65.

9. Kwon H, Kim D \& Kim JS (2017) Body fat distribution and the risk of incident metabolic syndrome: a longitudinal cohort study. Sci Rep 7, 10955.

10. Bombak A (2014) Obesity, health at every size, and public health policy. Am J Public Health 104, e60-e67.

11. Sacks FM, Bray GA, Carey VJ, et al. (2009) Comparison of weight-loss diets with different compositions of fat, protein, and carbohydrates. $N$ Engl J Med 360, 859-873.

12. Goss AM, Goree LL, Ellis AC, et al. (2013) Effects of diet macronutrient composition on body composition and fat distribution during weight maintenance and weight loss. Obesity (Silver Spring) 21, 1139-1142.

13. Rolls BJ, Roe LS, Beach AM, et al. (2005) Provision of foods differing in energy density affects long-term weight loss. Obes Res 13, 1052-1060.

14. Heymsfield SB, Van Mierlo CA, van der Knaap HC, et al. (2003) Weight management using a meal replacement strategy: meta and pooling analysis from six studies. Int $J$ Obes Metab Disord 27, 537-549.

15. Fung TT, Pan A, Hou T, et al. (2015) Long-term change in diet quality is associated with body weight change in men and women. J Nutr 145, 1850-1856.

16. Davis LM, Coleman C, Kiel J, et al. (2010) Efficacy of a meal replacement diet plan compared to a food-based diet plan after a period of weight loss and weight maintenance: a randomized controlled trial. Nutr $J \mathbf{9}, 11$.

17. Ello-Martin JA, Roe LS, Ledikwe JH, et al. (2007) Dietary energy density in the treatment of obesity: a year-long trial comparing 2 weight-loss diets. Am J Clin Nutr 85, 1465-1477.

18. Ledikwe J, Rolls B, Smiciklas-Wright H, et al. (2007) Reductions in dietary energy density are associated with weight loss in overweight and obese participants in the PREMIER trial. $\mathrm{Am}$ J Clin Nutr 85, 1212-1221.

19. Clifton P (2012) Effects of a high protein diet on body weight and comorbidities associated with obesity. Br J Nutr $\mathbf{1 0 8}$, Suppl. 2, S122-S129.

20. Astrup A, Raben A \& Geiker N (2015) The role of higher protein diets in weight control and obesity-related comorbidities. Int J Obes (Lond) 39, 721-726.

21. Gulati S, Misra A, Tiwari R, et al. (2017) Effect of high-protein meal replacement on weight and cardiometabolic profile in overweight/ obese Asian Indians in North India. Br J Nutr 117, 1531-1540.

22. Azadbakht L, Izadi V, Surkan PJ, et al. (2013) Effect of a high protein weight loss diet on weight, high-sensitivity C-reactive protein, and cardiovascular risk among overweight and obese women: a parallel clinical trial. Int J Endocrinol 2013, 971724.

23. Farnsworth E, Luscombe ND, Noakes M, et al. (2003) Effect of a high-protein, energy-restricted diet on body composition, glycemic control, and lipid concentrations in overweight and obese hyperinsulinemic men and women. Am J Clin Nutr $\mathbf{7 8}$, 31-39.

24. Rolls BJ (2014) What is the role of portion control in weight management. Int J Obes 38, Suppl. 8, S1-S8

25. Koliaki C, Spinos T, Spinou M, et al. (2018) Defining the optimal dietary approach for safe, effective and sustainable weight loss in overweight and obese adults. Healthcare (Basel) 6, E73.

26. Department of Statistics Malaysia (2018) Current population estimates, Malaysia, 2017-201. Department of Statistics Malaysia. Published online: 31 July 2018. https://www.dosm.gov.my/v1/ index.php? $\mathrm{r}=$ column/cthemeByCat\&cat $=155 \&$ bul_id $=\mathrm{c} 1 \mathrm{pqTnFjb}$ 29HSnNYNUpiTmNWZHArdz09\&menu_id=L0pheU43NWJw RWVSZklWdzQ4TlhUUT09 (accessed December 2018).
27. Abdullah N-F, Teo PS \& Foo LH (2016) Ethnic differences in the food intake patterns and its associated factors of adolescents in Kelantan, Malaysia. Nutrients 8, E551.

28. Mitra SR, Tan PY \& Amini F (2018) Effect of FTO rs9930506 on obesity and interaction of the gene variants with dietary protein and vitamin $\mathrm{E}$ on $\mathrm{C}$-reactive protein levels in multi-ethnic Malaysian adults. J Hum Nutr Diet 31, 758-772.

29. Dina C, Meyre D, Gallina S, et al. (2007) Variation in FTO contributes to childhood obesity and severe adult obesity. Nat Genet 39, 724-726.

30. Peeters A, Beckers S, Verrijken A, et al. (2008) Variants in the FTO gene are associated with common obesity in the Belgian population. Mol Genet Metab 93, 481-484.

31. Ri U, Badiu C, Cucu N, et al. (2015) The study of the rs9939609 FTO gene polymorphism in association with obesity and the management of obesity in a Romanian cohort. J Med Life $\mathbf{8}$, 232-238.

32. Devaraj S, Tang R, Adams-Huet B, et al. (2007) Effect of highdose alpha-tocopherol supplementation on biomarkers of oxidative stress and inflammation and carotid atherosclerosis in patients with coronary artery disease. Am J Clin Nutr 86, 1392-1398.

33. Scheurig AC, Thorand B, Fischer B, et al. (2008) Association between the intake of vitamins and trace elements from supplements and C-reactive protein: results of the MONICA/ KORA Augsburg study. Eur J Clin Nutr 62, 127-137.

34. Jung C-H \& Choi KM (2017) Impact of high-carbohydrate diet on metabolic parameters in patients with type 2 diabetes. Nutrients 9, E322.

35. Kabir M, Oppert JM, Vidal H, et al. (2002) Four-week lowglycemic index breakfast with a modest amount of soluble fibers in type 2 diabetic men. Metabolism 51, 819-826.

36. National Coordinating Committee on Food and Nutrition (2010) Malaysian Dietary Guidelines 2010. Malaysia: Ministry of Health.

37. WHO Expert Consultation (2004) Appropriate body-mass index for Asian populations and its implications for policy and intervention strategies. Lancet 363, 157-163.

38. WHO (2008) Waist Circumference and Waist-hip Ratio: Report of a WHO Expert Consultation. Geneva: World Health Orgnization.

39. Pickering TG, Hall JE, Appel LJ, et al. (2005) Recommendations for blood pressure measurement in humans and experimental animals: part 1: blood pressure measurement in humans: a statement for professionals from the Subcommittee of Professional and Public Education of the American Heart Association Council on High Blood Pressure Research. Circulation 111, 697-716.

40. Willett W (2012) Nutritional Epidemiology, third ed. Oxford: Oxford University Press.

41. Loy SL, Marhazlina M, Nor Azwany Y, et al. (2011) Development, validity and reproducibility of a food frequency questionnaire in pregnancy for the Universiti Sains Malaysia birth cohort study. Malays J Nutr 17, 1-18.

42. Suzana S (2009) Atlas of Food Exchanges \& Portion Sizes, 2nd ed. Kuala Lumpur: MDC Publishers Sdn Bhd.

43. Tee ES (1997) Nutrient Composition of Malaysian Foods, 4th ed. Malaysia: Ministry of Health: Malaysian Food Composition Database Programme.

44. Goldberg G, Black A, Jebb S, et al. (1991) Critical evaluation of energy intake data using fundamental principles of energy physiology: 2. Evaluating the results of published surveys. Eur J Clin Nutr 45, 583-599.

45. Ismail M, Chee S, Roslee R, et al. (1998) Predictive equations for the estimation of basal metabolic rate in Malaysian adults. Malays J Nutr 4, 73-80. 
46. Ainsworth BE, Haskell WIL, Whitt MC, et al. (2000) Compendium of physical activities: an update of activity codes and MET intensities. Med Sci Sports Exerc 32, S498-S504.

47. Wallace TM, Levy JC \& Matthews DR (2004) Use and abuse of HOMA modeling. Diabetes Care 27, 1487-1495.

48. Friedewald WT, Levy RI \& Fredrickson DS (1972) Estimation of the concentration of low-density lipoprotein cholesterol in plasma, without use of the preparative ultracentrifuge. Clin Chem 18, 499-502.

49. Alhassan S, Kim S, Bersamin A, et al. (2008) Dietary adherence and weight loss success among overweight women: results from the A to Z weight loss study. Int J Obes 32, 985-991.

50. Charan J \& Biswas T (2013) How to calculate sample size for different study designs in medical research? Indian J Psychol Med 35, 121-126.

51. Ambak R, Mohamad Nor NS, Puteh N, et al. (2018) The effect of weight loss intervention programme on health-related quality of life among low income overweight and obese housewives in the MyBFF@home study. BMC Womens Health 18, 17-23.

52. Wing R \& Phelan S (2005) Long-term weight loss maintenance. Am J Clin Nutr 82, 222S-225S

53. Dombrowski SU, Knittle K, Avenell A, et al. (2014) Long term maintenance of weight loss with non-surgical interventions in obese adults: systematic review and meta-analyses of randomised controlled trials. BMJ 348, g2646.

54. Strychar I (2006) Diet in the management of weight loss. CMAJ 174, 56-63.

55. Alberti KG, Zimmet P \& Shaw J (2006) Metabolic syndrome a new worldwide definition. A Consensus Statement from the International Diabetes Federation. Diabet Med 23, 469-480.

56. Mustapha FI, Omar ZA, Mihat O, et al. (2009) Addressing noncommunicable diseases in Malaysia: an integrative process of systems and community. BMC Public Health 14, Suppl. 2, S4.

57. Devaraj S, Singh U \& Jialal I (2009) Human C-reactive protein and the metabolic syndrome. Curr Opin Lipidol 20, 182-189.

58. Maachi M, Piéroni L, Bruckert E, et al. (2004) Systemic low-grade inflammation is related to both circulating and adipose tissue TNF $\alpha$, leptin and IL-6 levels in obese women. Int J Obes 28, 993-997.

59. Petelin A, Bizjak M, Cernelic-Bizjak M, et al. (2014) Low-grade inflammation in overweight and obese adults is affected by weight loss program. J Endocrinol Invest 37, 745-755.

60. Selvin E, Paynter NP \& Erlinger TP (2007) The effect of weight loss on C-reactive protein: a systematic review. Arch Intern Med 167, 31-39.

61. Wing RR, Blair EH, Bononi $\mathrm{P}$, et al. (1994) Caloric restriction per se is a significant factor in improvements in glycemic control and insulin sensitivity during weight loss in obese NIDDM patients. Diabetes Care 17, 30-36.

62. Pesta DH \& Samuel VT. (2014) A high-protein diet for reducing body fat: mechanisms and possible caveats. Nutr Metab (Lond) 11, 53 .

63. Parker B, Noakes M, Luscombe N, et al. (2002) Effect of a high-protein, high-monounsaturated fat weight loss diet on glycemic control and lipid levels in type 2 diabetes. Diabetes Care 25, 425-430.

64. Papakonstantinou E, Triantafillidou D, Panagiotakos DB, et al. (2010) A high-protein low-fat diet is more effective in improving blood pressure and triglycerides in calorie-restricted obese individuals with newly diagnosed type 2 diabetes. Eur J Clin Nutr 64, 595-602.

65. Gannon MC, Nuttall FQ, Saeed A, et al. (2003) An increase in dietary protein improves the blood glucose response in persons with type 2 diabetes. Am J Clin Nutr 78, 734-741.
66. Johnston CS, Sears B, Perry M, et al. (2017) Use of novel highprotein functional food products as part of a calorie-restricted diet to reduce insulin resistance and increase lean body mass in adults: a randomized controlled trial. Nutrients 9, E1182.

67. Wycherley TP, Moran LJ, Clifton PM, et al. (2012) Effects of energy-restricted high-protein, low-fat compared with standard-protein, low-fat diets: a meta-analysis of randomized controlled trials. Am J Clin Nutr 96, 1281-1298.

68. Noakes M, Keogh JB, Foster PR, et al. (2005) Effect of an energy-restricted, high-protein, low-fat diet relative to a conventional high-carbohydrate, low-fat diet on weight loss, body composition, nutritional status, and markers of cardiovascular health in obese women. Am J Clin Nutr 81, 1298-1306.

69. Briggs M, Petersen K \& Kris-Etherton P (2017) Saturated fatty acids and cardiovascular disease: replacements for saturated fat to reduce cardiovascular risk. Healthcare (Basel) 5, E29.

70. Freire RD, Cardoso MA, Gimeno SGA, et al. (2005) Dietary fat is associated with metabolic syndrome in Japanese Brazilians. Diabetes Care 28, 1779-1785.

71. Riccardi G, Giacco R \& Rivellese AA (2004) Dietary fat, insulin sensitivity and the metabolic syndrome. Clin Nutr 23, 447-456.

72. DiNicolantonio JJ, Lucan SC \& O'Keefe JH (2016) The evidence for saturated fat and for sugar related to coronary heart disease. Prog Cardiovasc Dis 58, 464-472.

73. Siri-Tarino PW, Sun Q, Hu FB, et al. (2010) Saturated fat, carbohydrate, and cardiovascular disease. Am J Clin Nutr $\mathbf{9 1}$, 502-509.

74. Ma Y, Li Y, Chiriboga DE, et al. (2006) Association between carbohydrate intake and serum lipids. J Am Coll Nutr 25, 155-163.

75. Nordestgaard BG \& Varbo A (2014) Triglycerides and cardiovascular disease. Lancet 384, 626-635.

76. Chalvon-Demersay $\mathrm{T}$, Azzout-Marniche $\mathrm{D}$, Arfsten $\mathrm{J}$, et al. (2017) A systematic review of the effects of plant compared with animal protein sources on features of metabolic syndrome. J Nutr 147, 281-292.

77. Soon JM \& Siong Tee E (2014) Changing trends in dietary pattern and implications to food and nutrition security in Association of Southeast Asian Nations (ASEAN). Int J Nutr Food Sci 3, 259-269.

78. Conlin PR (1999) The Dietary Approaches to Stop Hypertension (DASH) clinical trial: implications for lifestyle modifications in the treatment of hypertensive patients. Cardiol Rev 7, 284-288.

79. Sacks FM, Svetkey LP, Vollmer WM, et al. (2001) Effects on blood pressure of reduced dietary sodium and the Dietary Approaches to Stop Hypertension (DASH) diet. DASH-Sodium Collaborative Research Group. N Engl J Med 344, 3-10.

80. Appel LJ, Sacks FM, Carey VJ, et al. (2005) Effects of protein, monounsaturated fat, and carbohydrate intake on blood pressure and serum lipids: results of the OmniHeart randomized trial. JAMA 294, 2455-2464.

81. Pham-Huy LA, He H \& Pham-Huy C (2008) Free radicals, antioxidants in disease and health. Int J Biomed Sci $\mathbf{4}, 89-96$.

82. Singh U \& Jialal I (2004) Anti-inflammatory effects of alphatocopherol. Ann N Y Acad Sci 1031, 195-203.

83. Devaraj S, Leonard S, Traber MG, et al. (2008) Gammatocopherol supplementation alone and in combination with alpha-tocopherol alters biomarkers of oxidative stress and inflammation in subjects with metabolic syndrome. Free Radic Biol Med 44, 1203-1208.

84. Paolisso G, D'Amore A, Giugliano D, et al. (1993) Pharmacologic doses of vitamin $\mathrm{E}$ improve insulin action in healthy subjects and non-insulin-dependent diabetic patients. $A m J$ Clin Nutr 57, 650-656.

85. Manning PJ, Sutherland WHF, Walker RJ, et al. (2004) Effect of high-dose vitamin $\mathrm{E}$ on insulin resistance and associated 
parameters in overweight subjects. Diabetes Care 27, $2166-2171$.

86. Howarth NC, Saltzman E \& Roberts SB (2001) Dietary fiber and weight regulation. Nutr Rev 59, 129-139.

87. Weickert MO \& Pfeiffer AFH (2018) Impact of dietary fiber consumption on insulin resistance and the prevention of type 2 diabetes. J Nutr 48, 7-12.

88. Slavin J \& Green H (2007) Dietary fibre and satiety. Nutr Bull 32, Suppl. 1, 32-42.
89. Yu K, Ke M-Y, Li W-H, et al. (2014) The impact of soluble dietary fibre on gastric emptying, postprandial blood glucose and insulin in patients with type 2 diabetes. Asia Pac J Clin Nutr 23, 210-218.

90. Ma Y, Griffith JA, Chasan-Taber L, et al. (2006) Association between dietary fiber and serum C-reactive protein. Am J Clin Nutr 83, 760-766.

91. King DE (2005) Dietary fiber, inflammation, and cardiovascular disease. Mol Nutr Food Res 49, 594-600. 